\title{
Technology: Language teachers' digital and navigating skills in emergency education
}

\author{
Bambang Agus Darwanto - Sri Endah Setia Rini - Hesthi Herusatoto
}

DOI: $10.18355 /$ XL.2021.14.01.12

\begin{abstract}
The Covid-19 pandemic has forced school administrators and practitioners including teachers to find quick ways to mitigate the pandemic impacts on education including language education. When the pandemic hit, all parties were groping for new ways to conduct education (teaching and learning) in the emergency period. This research was intended to find out what skills teachers need to quickly transform themselves from the traditional to tech-rich teaching from home (TFH) in the pandemic outbreak with total school closure like that of the Covid-19. This research was descriptive quantitative with surveys and focus group discussions (FGD) with university teachers of different foreign languages to attain data. The results show that with different levels of digital and navigations skills, teachers have to be trained to attain the threshold level of various teachnological savviness to quickly serve. A diagram of a digital skills list is presented with hardware tools skills (skills to use gadgets) as the initial emergent skills to acquire and the learning tools skills (skills to access sources) as the last skills to train. All these trainings have to be carried out very quickly, and an around-the-clock mentoring system to give assistance to a teacher in an emergency teachnological situation must be provided. The findings should provide ideas as to how schools have to respond to a pandemic situation like the Covid-19 when a similar outbreak occurs in the future.
\end{abstract}

Key words: teachnology, digital skills, navigating skills, teaching from home, language education

\section{Introduction}

The abrupt school closure due to the Covid-19 outbreak in early March 2020 had forced schools and colleges in Indonesia and probably across the world to make a quick adaptation to the chaotic situation. All teachers and students suddenly had to stay home. The new term of "work from home" (WFH), "study from home" (SWH), and "teach from home" (TFH) were there and became trending. For a while, many schools and colleges might lose grips as to how they had to carry out teachinglearning. Schools had to come up with quick contingency educational decisions. An immediate and quick decision on the how-to-teach/learn was urgent while anticipating the probable incessant stumbling blocks in its implementation. The decision was urgent to mitigate the educational impacts during the pandemic. Classes have to run one way or another in this emergency state. Online education (learning and teaching) is inevitable. Teachers and students had to be immediately connected.

Teachers needed tools to teach. However, the teachnological skills for teachers previously had not been sufficiently attended before the pandemic hit; it had not yet been well mapped. Generally, the teachers had not had minimum knowledge and skills regarding teachnology. They have not received specific training on it. They usually explored the technology by themselves to meet the individual needs.

Before the pandemic, teachers could have felt comfortable with the level of teachnology that they had. They were in the comfort zone that email and WA were fully felt adequate for their teaching facilitation. This is because teaching was still fully offline with a few additional tasks delivered via email, WA, or Google Classroom. Some exercised on blended learning and flipped learning. These teachers

XLinguae, Volume 14 Issue 1, January 2021, ISSN 1337-8384, eISSN 2453-711X 
did not yet see the strategic potentials of further teachnology savviness because they might think that what they acquired was fully sufficient. When the pandemic hit, the comfort zone fell apart. The school management and the faculty were made more aware of the lack.

The Covid-19 pandemic has forced the academics to extensive use of technology. They have to operate their teaching fully online. Offline interaction is the most affected side of education. This situation can change the mode of teaching and learning into a new normal setting. The new normal requires a different teaching venue and teachnological skills.

Teachers had to get accustomed to living with their new academic life, with new teachnology that they may not have even imagined before. Nevertheless, that had different technological entry barriers. Eventually, they were forced to quickly learn new teachnology during the crisis. Teachnology and the way people learn a new language have been revolutionizing from the conventional broadcasting functionalities of technologies to the web technology of "folksonomies" and "mashups". This has changed the contents, the venues, and the ways people construct knowledge and acquire a new language. People use, share, and create content in ways fundamentally different from the previous eras.

Usually, different types and levels of teachnological skills are needed by different teachers. Some need to become more tech-savvy in using any teachnological tools to serve. They want to be more skillful with teachnologies especially with new authoring tools, presentation tools, and learning tools. This type of teacher always keeps pace with the teachnological currencies. This is the ideal model of self-developed teachers. This practice is aligned with the opinion that a teacher should keep pace with innovations and advances (Peredrienko et al., 2020:106). For digital natives, digital technology is just natural. However, for some digital immigrant teachers, they might experience tech apprehension that will affect their tech skills depth that they want to learn. They might set a boundary to their technological living room to secure their comfort zone. They would need the minimum tech functionalities to support their teaching profession.

To serve optimally, teachers today need both digital skills and navigating skills (Grand-Clement, 2017). Regarding these skills, Grand-Clement (2017:5) wrote that digital skills are the ability in using digital technologies and digital navigation skills, which include searching for information, emphasizing information, and checking the quality and authenticity of information, are a broader set of skills required by people to perform well in the digital world. Digital navigation skills are 'eternal skills' that are basically the same as the non-digital skills in the past which are still needed today. Research by Khodabandelou (2016) about barriers in incorporating technologies for teachers found out that the teachers were not sufficiently exposed to technology. They do not sufficiently know how to use technology to teach. Teachers, especially those aged 50 and above, were not willing to involve themselves in using the technology. The study reported that teachers gave the excuse that they were too old to learn the technology.

Teachers today must acquire at least the threshold level of teachnological skills to digitally serve. They should acquire the minimum skills of selecting, editing, applying, and integrating particular technology that supports their teaching (Liu et al., 2015:684). Some teachers may not be highly able to keep up with the technological currency that is rapidly revolutionizing. Whereas, one new technology can be obsolete tomorrow. One that teachers want to learn today may have got a replacement. This can be a frustrating challenge. Consequently and factually, the levels of needs for teachnologies can vary from one teacher to another. Getting them used to the teachnology requires a long process but then a new tech kicks in. As educational tasks are becoming more complex and the challenges are getting diverse, a new concept of

XLinguae, Volume 14 Issue 1, January 2021, ISSN 1337-8384, eISSN 2453-711X 
teaching and teacher training to conform with technologically related changes should be considered (Peredrienko et al., 2020:109). Universities must train and help teachers access the technologies and to learn how to use them and to apply them in the didactical context (Abdelrazeq et al., 2016:2). A newly introduced technology must meet the contextual requirements for its implementation.

The teaching contexts have been shifting. One of them is that courseware has been shifting into performance ware (Brown, 2006:5). Lecturing has been partly supplemented with learning artifact creation and innovation to show how one has learned. What students can perform matters more than what they can finish in tests. Technologies have to provide supports to the proposal. Students are required to provide digital artifacts of learning evidence. Teachers, consequently have to keep pace with it. Performance assessment according to O'Malley and Pierce (1996) requires students to show a response, create a product, or demonstrate knowledge application. Learning evaluation or assessment is no longer the same as traditional practices. It is no longer merely about what they can do in a test, but also what they can perform in a task. As far as language teaching and learning is concerned, for assessment purposes, students today can share their learning artifacts into blogs for especially texts and images to showcase their performance, ideas, and learning achievements. SlideShare for presentation formats, YouTube for video images, and such applications as SoundCloud for audio artifacts have become common media for the purpose.

People share to learn (Thomas J. P. et al., 2002:1). They network to get more informed. Other peoples' idea matters in the connectivist era (Siemens, 2004:3). This needs different learning skills. The ability to expand and maintain connectivity has become central in the teaching-learning processes. Teachers must have this type of capacity as well.

For teachers, different types of $\mathrm{T}$ in the TPACK (technology, pedagogy, content knowledge) need to be figured out. Teachers (and students) need to carry both digital skills and navigation skills (Grand-Clement, 2017:20). to function optimally. Teachers need to be aided not only with computer literacy but also with skills in how to make connections digitally. Especially for the "T", the keep-renewing authoring tools, learning tools, learner tools, testing tools, learning management tools, connecting tools are of a challenge for, especially, language teachers at this point in technology advancement. This fundamental change offers a wider range of tools and development opportunities for teachers and students (Dudeney \& Hockly, 2012). Even so, such a simple skill as screen sharing in the video conference apps can be a serious problem for a teacher if s/he has not been familiar with it. Technological skills, digital, and navigating skills, are important.

Teachers need to be able to digitally navigate, interact, and collaborate along with their students. In addition to navigation skills, interaction and collaboration are two essential skills for teachers/learners in the 21st century (Sahin, 2009; Jansen, Merwe, 2015;Bell, 2010;Bialik, Bogan, Fadel, Horvathova, 2015). In the traditional view, the last two are conducted via classroom-related tasks. Today, knowledge currency can be kept up to date by making connections through tagging, linking, attaching, or through mashups technologies. Personal knowledge is comprised of a network, which feeds into organizations, which in turn feeds back into the network and then continue to provide learning to the individual (Siemens, 2004:3). This cycle of knowledge development and personal network to the organization allows teacher-learners to remain current in their field through the connections they have formed in.

One of the key skills is then navigation skills (Brown, 2006:12-13). Navigationism, the new learning paradigm introduced by Brown (2006), is the umbrella perspective for developing educational policies, including the teaching and learning of a second language (L2). To further characterize learning in the beyond constructivism era,

XLinguae, Volume 14 Issue 1, January 2021, ISSN 1337-8384, eISSN 2453-711X 
Siemens suggested that "connections between specialized communities are important activities, and the connections that enable people to learn more are more important than our current state of knowing" (2004:3).

Similarly, Brown (2006:7) suggested paradigmatic shifts occurring in teaching and learning (education) from teaching centeredness to learning centeredness. Teachers do not teach but facilitate students' learning. Learning is not about reproducing what a teacher has taught but about giving a new contribution to knowledge and skills that a student can make and this can be promoted using digital technologies.

The 21st-century skills of communication, collaboration, creativity, critical thinking need to factor in the technological skills (including accessing skills, synthesizing, and authoring skills). Authoring tools and templates allow language teachers to develop their materials and tests (Chapelle \& Sauro, 2017:365). Other important skills that are not commonly attended yet need to be nurtured as part of technologies are networking or connecting skills.

Such skills as organizing information to facilitate learning in mashup technology are necessary. Gonzalez-Lloret and Ortega, 2014:10)noted that Web technology provides an unbundled environment never spotted before. The "broadcast" and "store" mode of the web technology of information exchange has far developed into a "mass" Internet connectivity based around the collective actions of online user communities rather than based on individual users (Selwyn in Oecd, 2010:24). Teachers need to carry a different type of teaching technologies today. The pedagogical, technological, and content knowledge (TPACK) of a teacher is challenged to the extreme that $\mathrm{s} / \mathrm{he}$ may feel that their knowledge and skills today are obsolete or irrelevant tomorrow. However, regarding teachnology, a certain level of teachnological skills threshold can be functionally satisfactory to teach in the digital era of today. Teachers 4.0 , as suggested by Abdelrazeq et al., must meet the new requirements and teaching behavior as the impact of digital technology. In this regard, universities have to prepare and support teachers in their new teaching role. University directors need to decide on a full adaption of new technology in the education system. Teachers need to be given training and chances to gain access to technology, to acquire skills is using it, and to use it in their teaching. (2016:2).

Any new technology for helping teachers to educate (teach and learn) in and outside classrooms has to be selected to accord with a set of informed teaching principles to handle the challenges that may pop up in its application. A selected technology should at least meet the threshold level of teachnology that can help teachers function optimally.

What about provisional teachnology skills in the pandemic like the Covid-19? In the pandemic situation, the "academic panic" is divided between university teachers who come from the new teachnological generation and those coming from the previous teachnological individuals; those who are adept at teachnology and those who are not. Both groups of teachers cannot avoid using current teachnologies. They cannot escape from the must-have digital and navigating skills of today. For instance, factually such as video conference technologies as Google Meet, Zoom, and the like were not well heard before. Now, teachers just have to select one from the list to teach. It is " $a$ conditio sine quanon".

This research is descriptive qualitative to explore and describe the teachnology that the faculty of foreign language schools in Indonesia urgently needs in the crisis of the Covid-19 pandemic when all schools are closed and both academics and students have to stay home. The beginning of the sudden outbreak is the most critical time to get all the educational staff and students ready with teaching arsenals including the digital and navigating skills that they might not have been sufficiently familiar with. The findings may inspire other schools to get equipped in a pandemic situation like the Covid-19 outbreak, once it hits in the future (hopefully not). The research question

XLinguae, Volume 14 Issue 1, January 2021, ISSN 1337-8384, eISSN 2453-711X 
addressed in this research is: To what level of emergency teachnological transformation do language teachers need to be equipped in an emergency situation like the Covid-19 outbreak when all schools are closed?

\section{Research Method \\ Instruments}

This research used both questionnaires and focused group discussions (FGDs) to explore the in-depth information regarding the teachers' lived experience especially during the emerging moment of the pandemic outbreak. The questionnaires tapped on the teachers' teachnology savviness before and after the emergency time of the sudden educational crisis. This was also to find information regarding the tech-lack, tech-need, and tech-want of the teachers in the critical situation.

The questionnaires were developed based on the 6 teachnological areas (hardware tools, LMS tools, authoring tools, learning tools, presentation tools, and connecting tools) assumed to be essential for teachers to carry out their teaching during a pandemic like the Covid-19. The questionnaires were built in Bahasa Indonesia to avoid misunderstandings compared to when they were developed in English. This is because the respondents were composed of those teaching English, French, and Korean. Questions were made in the checkbox grid format. The respondents would compare their teachnological abilities before the Covid-19 and now. The translation of the sample items is as follows:

On a scale of 5 ( 1 for very poor skills; 5 for expert skills), my ability in using authoring tools is...

1

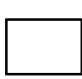

Before Covid

Now
2
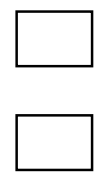

3
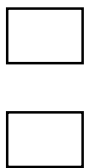

4
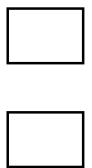

5
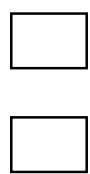

Some open-ended questions were provided to tap further information around the respondents' teachnological skills. The sample questions when translated are as follows.

1. What new applications that you had not learned, and you finally acquired now.

2. What have you done to increase or keep pace with the new technologies that you need to teach?

3. What applications that you suggest mastering for a teacher?

This research was also carried out through FGDs with groups of senior and junior university teachers to tap on their lived experience in the hectic time of the initial outbreak of the Covid-19. This was to know if the two groups of teachers encountered different digital teachnological experience. This would reveal what levels of teachnology was necessary to be trained to the two groups of teachers. Being necessary in this case is not meant for being fully sufficient, however. Technological complexity could vary for the same functionalities by different apps among different groups of teachers.

The core questions for the FGD when translated are as follows.

1. In the early Covid-19 outbreak, when you have to Teach from Home (TFH), what popped up in your mind regarding the transformation from teaching offline to teaching online?

2. When you experienced difficulties, kindly share anything regarding TFH.

XLinguae, Volume 14 Issue 1, January 2021, ISSN 1337-8384, eISSN 2453-711X 
3. TFH is difficult. What do you think?

4. In your experience, what skills that you think teachers had have to acquire to be able to serve in the TFH?

\section{Data and Analysis}

Data from the questionnaires were to reveal the teachers' needs, lacks, and wants. The data collected from the FGDs were to learn the most conditional teachnology that they need to serve in a closure situation. The data were coded based on the types of technologies that they (1) needed, (2) wanted, and (3) lacked. The teachnologies were subsumed into:

1. Authoring tools: The digital application for the creation of education materials (Hot Potato, VN editor, Kinemaster, Audacity, etc.)

2. Testing tools: Digital applications to help teachers develop online tests (Hot Potatoes, Google Form, etc.)

3. Sharing/presentation tools: The digital application for visualizing education materials and teaching contents (e.g. Prezi, PowerPoint, Slides, MindMapping, YouTube, IG, etc)

4. Learning management tools (LMS): The digital application to help administer the education process, to mount the course traffic, to share coursework including quizzes and tests, to keep track of students' participation and attendance. (E.g. Schoology, Google Classroom, Edmodo, etc)

5. Learning tools: The digital sources and applications that provide sources and digital programming for learning (e.g. www.4test.com; Pronunciation Checker, Grammarly, online dictionary, etc.)

6. Hardware tools: Equipment that teachers use for educating (e.g. cellphones, laptops, PC, etc.)

7. Conference tools: The digital equipment for making synchronous communication (e.g. Zoom, Meet).

8. Messenger tools: Applications that use the messenger platform for interaction (WA, Line, Twitter, etc).

Data were coded using NVivo11 and qualitatively analyzed for all pertaining phenomena worth attending when facing a sudden pandemic outbreak with school closures.

\section{Participants}

As many as 12 Indonesian university teachers finally responded to the questionnaires. The participants for the FGD were composed of senior teachers and junior teachers. Ten seniors were those of 41-50 years and above; while two juniors were all below 41 years old. They all were the teachers of different foreign languages: English, Korean, and French.

\section{Results}

The data indicate that, in general, the initial tech skills condition is as follows (1: Very Poor Skills; 5: Expert Skills). 


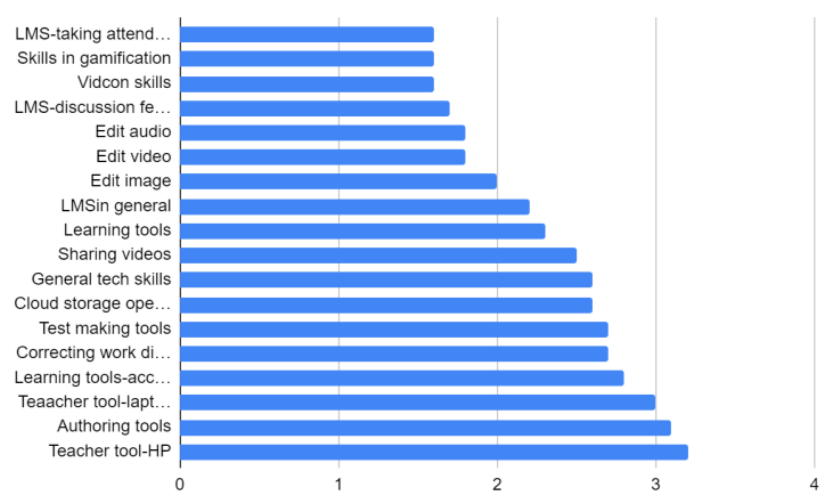

Figure 1. Teachers' initial tech skills condition

This chart indicates that before the Covid-19 outbreak, some teachnological skills have been commonly acquired but some others still need improvements. First, skills in the learning management system (LMS) should be given more priority. The teachers in general have not been familiar with various features offered in an LMS such as testing, discussion, and attendance. Such features need to be immediately improved by the school.

Second, the domain of authoring tools such as video, audio, and image editing along with the sharing tools (uploading skills) necessitates immediate training. Data show that the teachers' authoring skills are low.

Skills in teachnology are found varied. The findings suggest that it is not at all signifying that one skill can be neglected at all in the quick response training. All need to receive a refresher course. This is because, some teachers lack the necessary skills to teach from home (TFH), and this is accounted for in the distribution of the skill levels of each skill prompted in each questionnaire item.

Data indicate that the teachers' teachnological skills were averagely low with the distribution as indicated below.

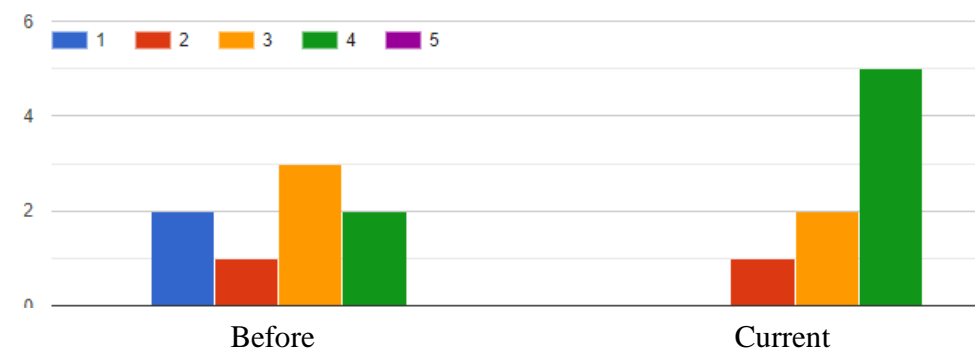

Figure 2. General Skills in Teachnology

Some teachers perceived that their tech skills fell within the very poor category as indicated in the blue bar. Some teachers have, however, reported that their teachnological skills were "very good" as indicated with the green bar. This condition was gradually improving with the training provided by the schools to respond to their lamenting. The right bars indicate the conditions after the training. 


\section{Authoring tools skills}

Similarly, their skills in using authoring tools were averagely low with the distribution as indicated below.

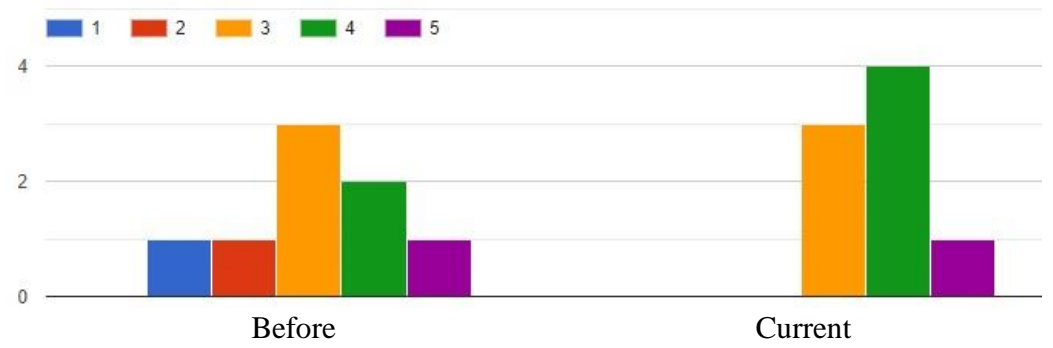

Figure 3. Authoring Tools Skills

Below are the authoring skills that the teachers need to improve.

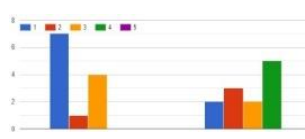

Audio Editing Skills

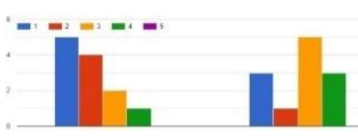

Video Editing Skills

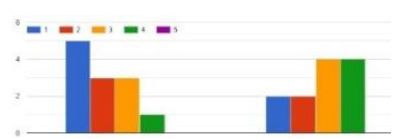

Image Editing Skills

Figure 4. Authoring Tools Skills Discrepancies

The figure above indicates how these teachers need immediate help to teach from home. This is because somehow these teachers need to share their lectures and learning materials in video, audio, and image formats.

\section{Presentation Tools Skills}

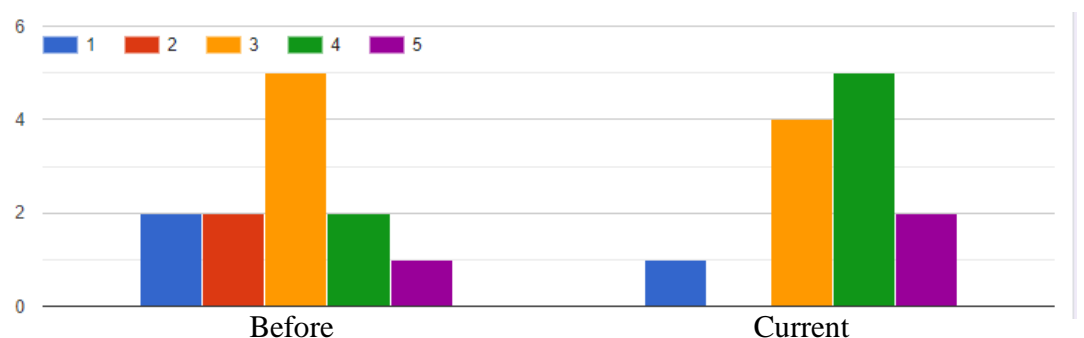

Figure 5. Presentation Tools Skills

Data indicate that these teachers provisionally need to be provided with emergency training to serve digitally. On the scale of five, the average score for all areas of technologies that have to be acquired to minimally serve in the initial outbreak of the pandemic was 2.5 with the scores ranges from one to four. This means that these teachers initially were not yet ready to teach using technologies. Amongst the areas of the different tools, they reported that they were most familiar with sharing tools, such as PowerPoint Presentation and Whatsapp. 


\section{Hardware Tools Skills}

On average, data reveal such an interesting phenomenon as indicated in the figure below. Teachers have been using laptops and cell-phones. However, when the teachnological aspects of these gadgets were factored in, many teachers admit knowing less about the use of them.

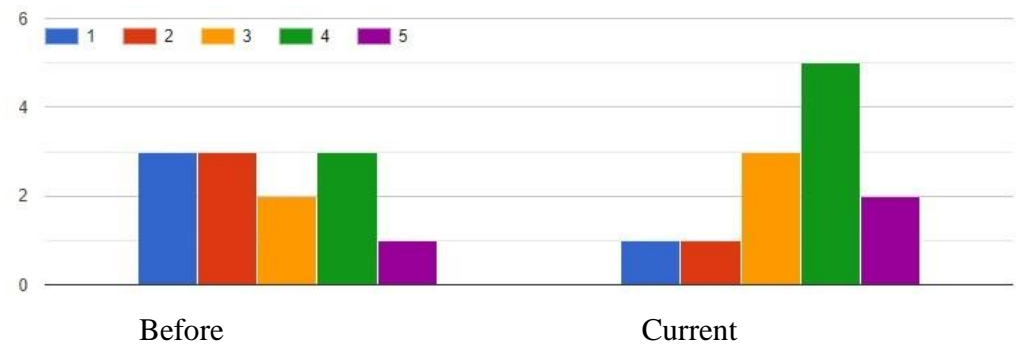

Figure 6. Hardware Tools Skills

The blue and red bars indicate a big number of teachers have not yet been familiar with the use of hardware tools to help to teach. It seems that they simply use the gadgets for "normal" uses.

\section{Learning Tools Skills (grammar checker)}

Data show a similar trend over the distribution of skill levels regarding the ability to use technologies to access sources of knowledge. These teachers' learning tools skills improved after emergency training.

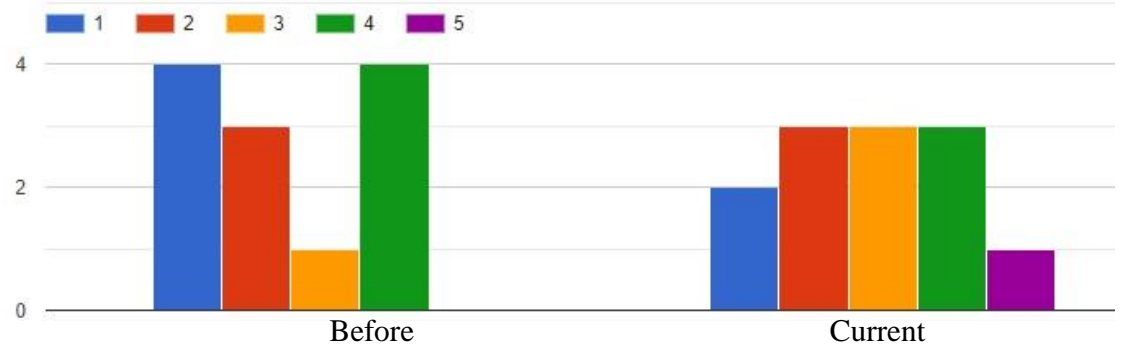

Figure 7. Learning Tools Skills

The number of teachers with barely any learning tools skills decreased after the emergency training.

\section{LMS Tools Skills}

The next serious area that needs immediate attention concerns with their LMS tools skills. Data indicate that many reported that they were not ready to use an LMS to help their teaching when they had to WFH. 


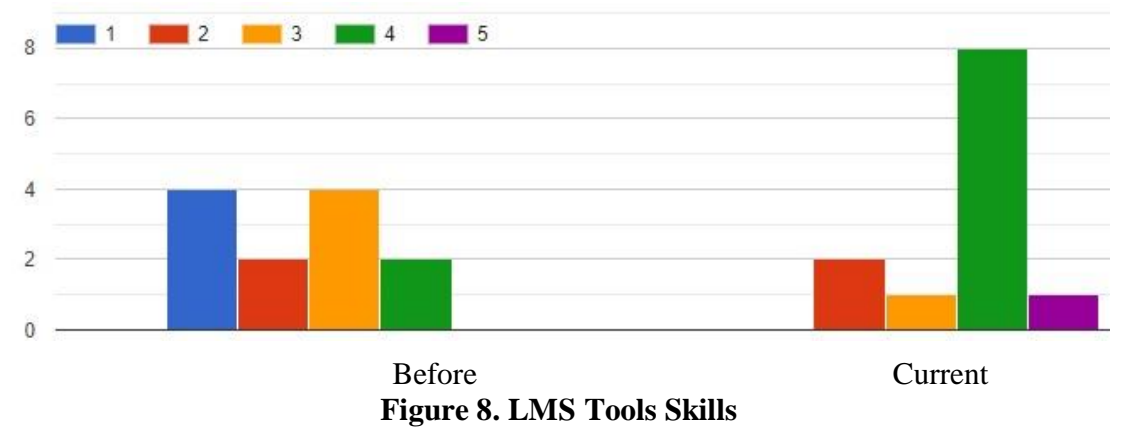

After a quick emergency training, they reported that their skills in using an LMS especially Google Classroom increased.

\section{Sharing Tools Skills}

Sharing tools skills are required to present all media in the forms of file sharing, link sharing, file upload, video upload, slide share upload, and messenger-based apps sharing. Many of the skills are required to enrich their LMS, to rectify their lectures, and to increase teacher-student interactions to make teaching-learning more individually-focused.

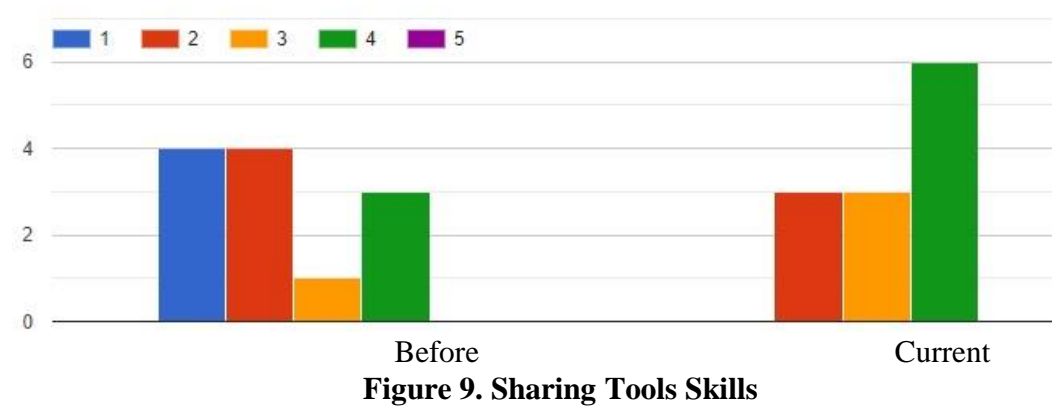

The blue, red, and yellow bars indicate that these teachers in the sudden pandemic outbreak had not sufficient confidence that they can really TFH. This information is also accounted for in the FGD that after quick training, these teachers said that they increased their skills in sharing files, links, videos, etc.

\section{Conference Tools Skills}

Conference tools are digital equipment for making synchronous and asynchronous communication. The skills level distribution is visualized below. 


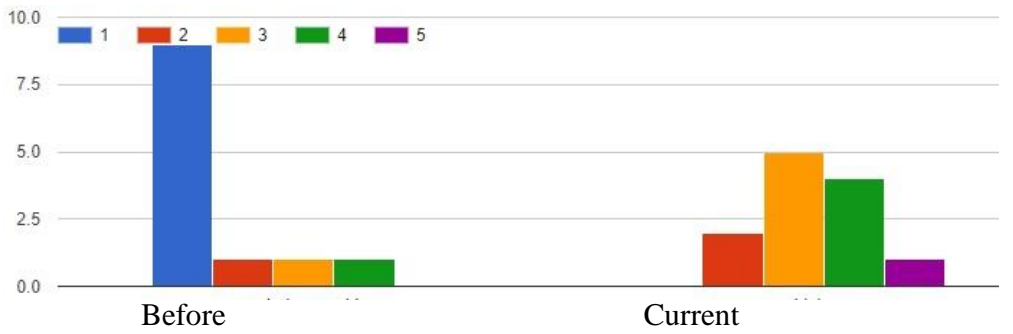

Figure 10. Conference Tools Skills

The FGD confirmed that most of the teachers said that they did not have enough skills or they had no skills to manage conferences. After training, they increased their skills even though more than $50 \%$ said that they still did not have enough skills to manage conferences. They still were not confident enough to do conferences on their own.

\section{Gadget Tools Skills}

Almost all teachers had a smartphone and a laptop, and they have already had skills in accessing those gadgets. Yet, most of them used it only to make presentations, especially using PowerPoint presentations. They did not synchronize the applications on their handphones. They used their handphones only to communicate with their students' using Whatsapp or to access social media such as Instagram and Facebook. The skills distribution before and after the pandemic outbreak is seen in Figure 11.

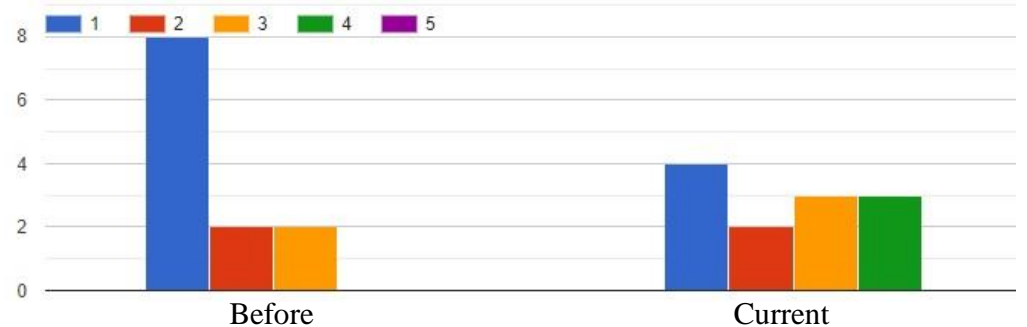

Figure 11. Gadget Tools Skills

After the training, the teachers' skills increased. They turn to be able to use smartphones to manage LMS, to make forms, and to edit or make videos.

\section{Gamification Skills}

Gamification skills are skills to teach or test students through games. There is a lot of game application learning, such as Quizizz, Kahoot, and Socrative. Only three respondents claimed that they already mastered game applications.

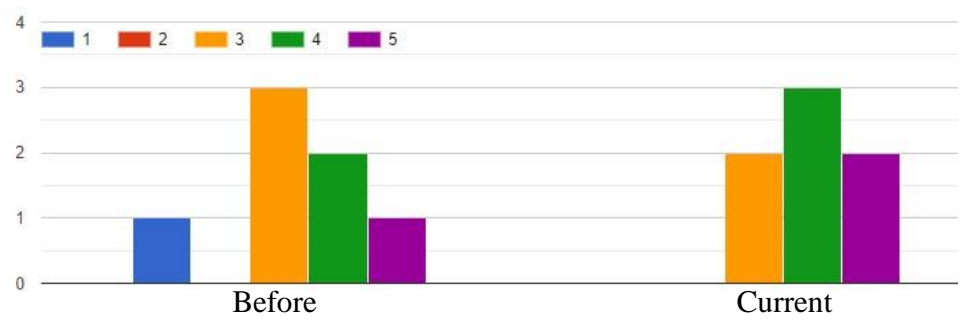

Figure 12. Gamification Skills

XLinguae, Volume 14 Issue 1, January 2021, ISSN 1337-8384, eISSN 2453-711X 
After training, the number of respondents who were able to do gamification increased. However, the FGD gave various perspectives to gamification. Some lecturers thought that it was not really important to acquire this type of skills to serve in an emergency situation as that of the pandemic sudden hit.

\section{Learning Tools Skills}

Learning tools skills are the digital sources and applications that provide sources and digital programming for learning (e.g. www.4test.com; Pronunciation Checker, Grammarly, online dictionary, etc.)

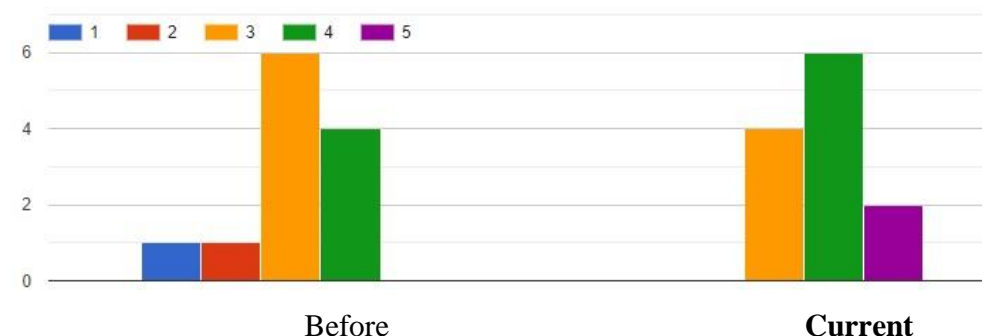

Figure 13. Learning Tools Skills

After training, teachers said that now they can use more digital sources and applications to find more information.

\section{Types of Application Needed}

From the questionnaires and FGDs, it can be seen that the teachers need to know some tools as follows:

Table 1. of teachnology tools

\begin{tabular}{|l|l|}
\hline \multicolumn{1}{|c|}{ Types } & \multicolumn{1}{c|}{ Examples } \\
\hline Teacher Tools (Hardware) & Laptop, PC, handphone \\
\hline LMS & Google Classroom, Schoology, Moodle \\
\hline Presentation Tools & $\begin{array}{l}\text { Presentation tool (PPT, WPS), Share screen, } \\
\text { Video presentation }\end{array}$ \\
\hline Authoring Tools: & Faststone, PowerPoint voice-over, Bandicam \\
Video recording & Powtoon, Toonly \\
Video presentation making & Kinemaster \\
Video editing & Audacity \\
Audio editing & Video conference: Zoom, Teams, Google \\
\hline Sharing management/connecting & Meet \\
tools & Chatting: WhatsApp \\
\hline Learning Tools & Online dictionary, translate tool \\
\hline
\end{tabular}

\section{Discussion}

Teachers with their technological entry barriers regardless of their age experienced sudden confusion as to how teaching should be carried out in the sudden pandemic outbreak. The confusion can be attributed to several grounds. First, data show that WFH is a new concept. Teaching students from home was still beyond imagination. They have less know-how regarding teaching and learning (education) administration from home. Second, even when they have got the idea of virtual classes, many have not been provided with supporting materials such as internet connection at home and online education materials. Third, many do not have sufficient digital and navigating

XLinguae, Volume 14 Issue 1, January 2021, ISSN 1337-8384, eISSN 2453-711X 
skills to manage a virtual class. Many are lacking skills in operating authoring tools, presentation tools, learning management tools, teacher tools, and connecting tools. These tools simply have to be sufficiently acquired to teach.

Hussin (2018) listed the most fundamental skills for a teacher. He suggested that teachers must have skills in authoring tools such as recording and editing audios and making annotated attractive and interactive video contents, skills in connecting tools like using social networking websites and social bookmarking websites and sharing resources with students, skills in authoring tools that is creating visually attractive contents, skills in participatory/interaction tools such as using blogs and wikis, skills in presentation tools like creating appealing presentations, skills in participatory/interaction tools such as making e-portfolios, and skills in evaluations tools that is creating non-traditional quizzes (Hussin: 95).

The school administration was aware of the provisional characteristics of the teachnological problems for the teachers. The FDG with the school managers reveals that in response to the emergency situation, they carried out non-stop virtual meetings to find quick solutions to the provisional situations. They did a quick survey as to what the teachers lack and want to help to teach digitally.

The school managers came up with the following policies regarding the threshold (emergency) requirements for teachers to teach virtually:

1. some skills in using LMS

2. some skills in LMS's communication traffic management, coursework management (including learning materials, testing, and attendance taking), and mashup skills

3. some skills in creating learning materials of different media: audio, video, and texts 4. some connecting skills such as uploading and sharing.

These skills are considered significant. During the pandemic, learning takes place in a new digital ecology. Currently, for teachers and learners, everywhere is a school, and everyone is a teacher. The ecology is composed of complex settings and unpredictable input often dissimilar to what students learn in class. Teachers need to somehow acquire both digital and navigating skills to successfully serve when offline schooling is not probable. They need to be equipped to anticipate such educational shifts in the pandemic situation as follows.

The FGD with the university teachers also indicates that they are aware of their poor skills in conducting online teaching. At the beginning of the pandemic, they did not know what to do. Some teachers who already used LMS as their teaching media said that they were not surprised when they had to teach using LMS, but they only shared slides presentation and gave students online exercises and tasks. At that time, students complained about the huge number of tasks and no explanation on slide presentations. Teachers were not yet ready to conduct online teaching using conference tools or to make video presentations. In this case, the school managers decided to try lots of video conferences to decide which tool can be easily used by the teachers. The decision taken is based on the stability of the tool. Yet, no decision was made to make video presentations.

During the pandemic, the school managers tried to find a solution to overcome the teachers' weaknesses. Having joined some training and webinars, the school managers decided to give training and coaching to the teachers. They asked the teachers who have technological skills to give training and coaching. Junior teachers (ages between 31-40 years old) did not have any difficulty in adapting to technology. They could master the teachnological skills taught quickly. Middle teachers (ages between 41-50 years old) have different abilities. Most of them could not master technology quickly. They needed a longer time to understand. Most of them understood that they had to know how to use a laptop and a mobile phone especially the smartphone. There was one teacher that did not have a smartphone, but in this

XLinguae, Volume 14 Issue 1, January 2021, ISSN 1337-8384, eISSN 2453-711X 
pandemic era, she started using a smartphone to facilitate the teaching-learning process.

After knowing how to use a laptop and smartphone, skills that are important to be mastered are LMS, presentation tools, connecting/sharing management tools, and authoring tools. Those are the necessary tools to be mastered during the pandemic. When the teachers were asked about types of LMS, they preferred Schoology because it is easy to use and more interesting. In Schoology, all functions are already there. There are posting updates, uploading materials, making quizzes, discussions, attendance, and grade books. The school management decided to use Google Classroom because of the stability and ease of access for some students with low bandwidth. One teacher recommended Moodle, but it needs a big server to manage the LMS. For presentation tools, the teachers still preferred to use slide presentations and most of them had already added more explanations in their slide presentations to help students understand the material. To prepare a video presentation, the teachers preferred using Faststone or PowerPoint voice over. However, some teachers said that it was not necessary to prepare a video presentation because they still could explain the materials at Zoom meetings. Most teachers said that it was necessary to give students a video presentation so that in Zoom meetings they only needed to discuss the material given before the Zoom meeting or to practice English. They thought that students could learn the material by watching the video explanation. The teachers with advanced skills in technology always used videos to explain the materials, and sometimes they used video editing such as Kinemaster or video presentation makers such as Powtoon or Toonly, to make their video more interesting. For listening audios, the teachers also used audacity to edit audios.

When asked about gamification, they said that this was not a necessary thing to be applied in teaching. When asked how they shared their files with students, all of them said that they uploaded it on the LMS if the size of the file was not too big. If the size was big, they uploaded it on YouTube or cloud storage. In the early pandemic, they did not know how to upload a video on YouTube, but most of them had already known how to use cloud storage. Some students did not have good internet access, so some teachers shared their files on the WhatsApp group. To connect with the students, all teachers made WA groups to contact the students if there was a sudden announcement. The teachers also had the skills to use a conference tool that is Zoom meetings. Almost all teachers could open and manage the conference tool such as login, share conference link to students, mute and unmute audio, hide and unhide video, use chat, record, etc.

Another tool asked is learning tools. Learning tools skills are digital sources and applications that provide sources and digital programming for learning (e.g. www.4test.com; Pronunciation Checker, Grammarly, online dictionary, etc.). The teachers stated that they sometimes used an online dictionary or Google translate to find words or terms they did not know. One teacher said she used the Sound of Text to check how to pronounce some words.

Some interesting things were found in senior teachers (age up to 51 years old). There were three senior teachers with three different competencies. One teacher had good adaptative skills to technology, one had a low skill, and one teacher had a very low skill. This senior group needed a longer time to learn how to use those technologies. They could not learn in a big-sized group. One teacher could learn the technology independently, but two teachers need more attention. They need private coaching. One teacher could finally adapt to the technologies after some intense coaching. One teacher claimed that she already mastered the use of LMS and conference, but apparently, she still did not know what to do to manage the LMS and conference by herself. She asked a student to be her assistant as she did not want to learn more about technology. She said that she did not need more preparation before the teaching-

XLinguae, Volume 14 Issue 1, January 2021, ISSN 1337-8384, eISSN 2453-711X 
learning process. When asked about her skills before and after the Covid-19, she confidently said that her skill improved significantly especially in managing LMS and conference. She could not accept that she had to learn something new from her junior; thus, she did not want to learn something new from the training. She expected that the Person in Charge does those things for her. She claimed that she already understood what was given in the training, but she did not understand at all.

Teaching should also be about where and how knowledge can be attained independent of classroom instructions. Real-life communication phenomena can be unpredictable yet provide rich relevant information. Teachers need to transform from the offline mode to the online mode, and the transformation is not merely about moving teaching from physical to virtual classrooms. In language teaching, at least three principles in the teaching of language in the connectivist era need to be considered. First, teachers' skills and experience in leading students to learning independence is significant.

Ivanovska (2014:353) said that learner autonomy in language education is interpreted in various ways in the literature using various terms, such as (1) learner autonomy, (2) learner independence, (3) self-direction, (4) autonomous learning, (5) independent learning and all these items have been used to refer to similar concepts.

Little $(2007: 14,22)$ noted that the term autonomy derives from learner-centered theories within the constructivist epistemologies as also referred to as "independent learning". He denoted that learner autonomy is a social-interactive as well as an individual-cognitive phenomenon. He further contended that autonomous learners take the initiative of carrying out learning-related actions. As such, students feel more competent in the things they do or carry more learning capacity within their learning arsenals.

Second, evaluation of students' learning is about what the student can do, not about what they think they can do. Erben, Cruz, and Thornton, (2009:153) noted that there are basically 3 types of alternative performance-based assessment: performance (i.e. in-person acting/doing), projects, and portfolios. These assessment modes are highly enabled by technology.

Assessment should focus more on students' performative outputs. What makes the three different from other tests is that the English language learners (ELLs) are assessed based on their language performance (output) not merely their language competence. A direct testing technique is used to evaluate the ELLs' language performance. Students write when their writing skills are to investigate; they speak when their speaking skills are to evaluate. Also, ways to evaluate learners' progress are not limited only to tests.

Third, teaching should nurture collaboration and interaction as the practice of the notion of "knowledge in the making". Laal and Laal (2012:1) noted that collaborative learning is an approach that encourages students to work together to solve problems, complete assignments, or make products. Johnson in Laal and Laal noted that learning is collaborative if class members are required to depend on one another to attain the goal. This is when anyone fails to do their part, the rest also get the consequences. They need to feel that they are connected and can succeed together. Together they work and support each other to learn, seek and share knowledge, give feedback, develop critical thinking, teach and support one another. Each student is responsible for performing their role, and class members evaluate regularly their performance and try to make improvement to perform better (2012:493).

In short, according to Johnson in Laal and Laal (2012:493), collaborative learning should carry in it (1) positive interdependence, (2) evaluation, (3) personal responsibility, (4) social skills, and (5) considerable interaction with others. All of these, with sufficient teachnological skills, can be put into practice. Teachers can use such learning-teaching technology as offered in www.pcsystem.web.id, or other applications. Today, teaching should integrate a rigorous coaching mechanism as a

XLinguae, Volume 14 Issue 1, January 2021, ISSN 1337-8384, eISSN 2453-711X 
priority. With communication technology, a learning management system can make learning more individualized. One student's needs can be different from the others. This needs teachnological skills beyond the entry levels, however. This can be nurtured in a long-termed period after the entry barrier level has been leveled up.

In an emergency situation, some threshold teachnological level needs to be ensured for teachers to serve:

1. Authoring tools skills

Selecting the most proper authoring tools can be painful because it requires information about every detail of all. For this reason, choosing the best authoring tools requires needs assessment. Teachers need to determine the minimum functionalities that best suit the emergency needs. In this regard, the school administration should tap information about various authoring tools from different users based on the results of the general needs analysis, from which they must select the most proper tools to be taught to all teachers in a very brief course.

2. Sharing/presentation tools skills

Most teachers are familiar with MS PowerPoint. However, they need to be guided to share it online either into the asynchronous platform like SlideShare, shared links, or the synchronous platforms like Zoom, Meet, and other similar applications. Note that data show that almost all teachers were not familiar with video conference apps.

3. Learning management tools (LMS) skills

Different LMS offer some different features. Some are in a WYSIWYG (what you see is what you get) mode, while the rest are not. Teachers prefer to use one with the WYSIWYG platform and easy to operate. The choices are either Google Classroom or Schoology.

4. Learning tools skills

The fact that many teachers have not got the experience in accessing various online teaching-learning sources needs to be attended in the emergency training. The skills to help organize their "library" also need to be trained. Such simple skills as saving a document in the Drive (cloud) and organizing the documents in Mendeley or Zotero, for instance, can be a serious challenge for teachers with entry levels.

5. Gadget tools skills

A cell phone is not really a "phone", literally. People do not use this gadget to frequently make calls. They use it more as access to all kinds of apps provided in the store. However, rarely do teachers use this gadget to help to teach. Data show that they do not know yet that it can be used as a limited synchronous LMS. They can conduct conferences with a limited number of participants. Many have not learned that it can ease up downloads and online media saving. This also needs to be introduced to provide back-up gadgets for their TFH.

6. Testing tools skills

Somehow, testing is necessary. First, teachers need to be provided with a refresher course to get them tuned to how to test creation can be developed using an online app such as Google Form or using features built-in an LMS such as Schoology. Second, after they are sufficiently familiar with any of the online testing platforms, they can be introduced to offline software like Audacity or Cool Edit (for listening tests).

\section{Conclusion}

This research has revealed what teachers need to minimally serve in the TFH activity. Teachers with different technological entry barriers must be provided with emergency training on the threshold level of teachnology. When arranged based on the levels of urgency, the teachnological skills that they need to be guided is as follows.

XLinguae, Volume 14 Issue 1, January 2021, ISSN 1337-8384, eISSN 2453-711X 


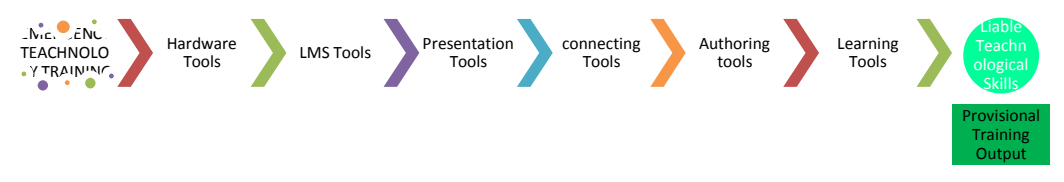

This workflow shows that first, emergency training should be quick and had better be provided in not more than two weeks. To follow up, a peer-coaching system needs to be considered. The college can assign different teachers who are good at one teachnological tool to serve as a Person in Charge (PIC) or a consultant for those who need further guidance. Continuous group discussions about an app can be enforced. Whatsapp Group (WAG) has proven to be effective for the purpose.

\section{Suggestion}

This research has not looked into situations experienced by the students. Information regarding the learnological condition among the students is significant to be revealed. This is to provide a complete emergency education framework as to how an emergency education when school closure takes place should be conducted

To close, the pandemic is somehow a blessing in disguise. Teachers' teachnological skills and their teaching efficacy increased.

\section{Bibliographic references}

ABDELRAZEQ, A. - JANSSEN, D. - TUMMEL, C. - RICHERT, A. - JESCHKE, S. 2016. Teacher 4.0: Requirements of the Teacher of the Future in Context of the Fourth Industrial Revolution. In: ICERI2016 Proceedings, 1 (November), pp. 82218226. Available online: https://doi.org/10.21125/iceri.2016.0880

BELL, S. 2010. Project-based Learning for the 21stCcentury: Skills for the Future. IN: The Clearing House: A Journal of Educational Strategies, Issues and Ideas, vol. 83 n.2, pp. 39-43. Available online: https://doi.org/10.1080/00098650903505415

BIALIK, M. - BOGAN, M. - FADEL, C. - HORVATHOVA, M. 2015. Education for the 21st Century: What should Students Learn. In: Center for Curriculum Redesign, vol. 3 n.4, pp. 415-420. Available online: www.curriculumredesign.org

BROWN, T. H. 2006. Beyond Constructivism: Exploring Future Learning Paradigms beyond Constructivism, Navigationism in the Knowledge Era. In: On The Horizon, vol. 4 n. 3, pp. 1-15.

CHAPELLE, C. A. - SAURO, S. 2017. The Handbook of Technology and Second Language Teaching and Learning. Available online: https://www.wiley.com/enus/The+Handbook+of+Technology+and+Second+Language+Teaching+and+

Learning-p-9781118914038

DUDENEY, G. - HOCKLY, N. 2012. ICT in ELT: How did we get here and where are we going? In: ELT Journal, vol. 66, n.4, pp. 533-542. Available online: https://doi.org/10.1093/elt/ccs050

GONZALEZ-LLORET, M. - ORTEGA, L. 2014. Task-based Language Teaching: Issues, Research, and Practice (6th ed.). John Benjamins Publishing Company.

GRAND-CLEMENT, S. 2017. Digital Learning: Education and Skills in the Digital Age. $\quad$ pp. 1-23. Available online: https://www.rand.org/content/dam/rand/pubs/conf_proceedings/CF300/CF369/RAND _CF369.pdf

HUSSIN, A. A. 2018. Education 4.0 Made Simple: Ideas for Teaching. In: International Journal of Education and Literacy Studies, vol. 6, n. 3, pp. 92-98. 
JANSEN, C. - MERWE, P. Van Der. 2015. Teaching practice in the 21st century: Emerging trends, challenges, and opportunities. Horizon Research Publishing.

KHODABANDELOU, R. 2016. Exploring the Main Barriers of Technology Integration in the English Language Teaching Classroom: A Qualitative Study. In: International Journal of Education and Literacy Studies, vol.4, n.1, pp. 53-58. https://doi.org/10.7575/aiac.ijels.v.4n.1p.53

LIU, S. - LIU, H. - YU, Y. - LI, Y. - WEN, T. 2015. TPACK: A New Ddimension to EFL Teachers' PCK. In: Journal of Education and Human Development, vol. 3, n.2, pp. 681-693.

O’MALleY, J. M. - PIERCE, L. V. 1996. Authentic Assessment for English Language Learners: Practical Approaches for Teachers (1st ed.). Longman.

OECD. 2010. Inspired by Technology, Driven by Pedagogy Inspired by Technology. In: Educational Research. Available online: https://doi.org/10.1787/9789264094437en

PEREDRIENKO, T. - BELKINA, O. - YAROSLOVA, E. 2020. New Language Learning Environment: Expectations and the Role of Teacher 4.0. In: International Journal of Instruction, vol. 13, n.3, pp. 105-118.

SAHIN, M. C. 2009. Instructional Design Principles for 21st Century Learning Skills. In Procedia - Social and Behavioral Sciences, vol.1, n.1, pp. 1464-1468. Available online: https://doi.org/10.1016/j.sbspro.2009.01.258

SIEMENS, G. 2004. Connectivism: A Learning Theory for the Digital Age. In: International Journal of Instructional Technology and Distance Learning, vol. 2, n.1, pp. 3-10.

THOMAS, J. P. - MAES, R. - VERNOOIJ, F. T. J. 2002. Learning by Sharing: A Model for Life-long Learning. In: Educational Innovation in Economics and Business vol. VI, pp. 189-198. https://doi.org/10.1007/978-94-017-1390-0_13

Words: 7704

Characters: $50666(28,15$ standard pages $)$

Drs. Bambang Agus Darwanto, M.A.

English Department

LIA School of Foreign Languages (STBA LIA)

Yogyakarta,

Indonesia

agusdarwanto66@gmail.com

Sri Endah Setia Rini, S.S., M.Pd.

English Department

LIA School of Foreign Languages (STBA LIA)

Yogyakarta,

Indonesia

sriendah.setiarini@gmail.com

Hesthi Herusatoto, S.S., M.A.

English Department

LIA School of Foreign Languages (STBA LIA)

Yogyakarta,

Indonesia

hesthi.stbalia@gmail.com

XLinguae, Volume 14 Issue 1, January 2021, ISSN 1337-8384, eISSN 2453-711X 